\title{
A!
}

This is an electronic reprint of the original article.

This reprint may differ from the original in pagination and typographic detail.

Linko, Veikko; Mikkilä, Joona; Kostiainen, Mauri A.

\section{Packaging DNA origami into viral protein cages}

Published in:

Virus-Derived Nanoparticles for Advanced Technologies

DOI:

10.1007/978-1-4939-7808-3_18

Published: 01/01/2018

Document Version

Peer reviewed version

Please cite the original version:

Linko, V., Mikkilä, J., \& Kostiainen, M. A. (2018). Packaging DNA origami into viral protein cages. In C. Wege, \& G. P. Lomonossoff (Eds.), Virus-Derived Nanoparticles for Advanced Technologies (Vol. 1776, pp. 267-277). (Methods in Molecular Biology; Vol. 1776). SPRINGER. https://doi.org/10.1007/978-1-4939-7808-3_18

This material is protected by copyright and other intellectual property rights, and duplication or sale of all or part of any of the repository collections is not permitted, except that material may be duplicated by you for your research use or educational purposes in electronic or print form. You must obtain permission for any other use. Electronic or print copies may not be offered, whether for sale or otherwise to anyone who is not an authorised user. 


\section{Packaging DNA Origami Into Viral Protein Cages}

\section{Veikko Linko, Joona Mikkilä and Mauri A. Kostiainen*}

Biohybrid Materials, Department of Biotechnology and Chemical Technology, Aalto University, 00076 Aalto, Finland.Email: mauri.kostiainen@aalto.fi

\section{Summary}

DNA origami technique is a widely used method to create customized, complex, spatially well-defined two- (2D) and three-dimensional (3D) DNA nanostructures. These structures possess a huge potential to serve as smart drug-delivery vehicles and molecular devices in various nanomedical and biotechnological applications. However, so far only little is known about the behavior of these novel structures in living organisms or in cell culture/tissue models. Moreover, enhancing pharmacokinetic bioavailability and transfection properties of such structures still remains a challenge. One intriguing approach to overcome these issues is to coat DNA origami nanostructures with proteins or lipid membranes. Here, we show how cowpea chlorotic mottle virus (CCMV) capsid proteins (CPs) can be used in coating DNA origami nanostructures. We present a method for disassembling the native CCMV particles and isolating the pure CP dimers, which can further bind and encapsulate a rectangular DNA origami shape. Owing to the highly programmable nature of DNA origamis, packaging of DNA nanostructures into viral protein cages could find imminent uses in enhanced targeting and cellular delivery of various active nano-objects, such as enzymes and drug molecules. 
Keywords: Nucleic acids, DNA nanotechnology, DNA origami, Self-assembly, Virus capsid protein, Electrostatic assembly

\section{Introduction}

The specific binding between nucleobases (Watson-Crick base pairing) can be exploited in creating DNA-based nanomaterials and devices for numerous biomedical applications. The first DNA nanostructures were proposed and demonstrated by Nadrian 'Ned' Seeman in the 1980s (1). Since then, various design strategies for DNA nanoarchitectures have been presented $(2,3)$. One of them is a DNA origami (4), which has proven to be a remarkably robust and straightforward method. With the DNA origami technique, it is possible to create customized and complex two- and three-dimensional nano-objects with nanometer-scale precision $(4,5)$. Most commonly, origamis are formed by folding a long single-stranded DNA scaffold strand into a desired shape with a set of designed oligonucleotides, i.e. staple strands. These staples are unique in sequence and they bind to specific locations at the scaffold strand, thus driving the exact assembly of the desired origami shape. Importantly, DNA origami can be used to arrange different materials such as enzymes (6), metal nanoparticles (7), and carbon nanotubes (8). The authors have recently demonstrated how DNA origami shapes can be utilized in creating enzymatic nanoreactors (9) and metallic nanostructures (10), and how the structures can be efficiently positioned and anchored on different substrates $(11,12)$.

Due to their biocompatibility and modularity, DNA origamis are seen as promising candidates for developing biomedical delivery vehicles carrying drug molecules, 
functional binding sites and cell-targeting ligands $(13,14)$. Although the recent studies indicate that e.g. DNA nanotubes (15), CpG-sequence-coated DNA origamis (16) and various other shapes containing drug molecules $(17,18)$ can enter cells to some extent, the highly polar nature of the DNA structures seems to prevent efficient transfection (19). Besides widely used transfection reagents, designed intercalators (20), and lipid-membrane coatings (21) could be utilized to enhance the transfection efficiency or pharmacokinetic bioavailability of the DNA nanostructures. However, other types of further improved and sophisticated delivery systems are still urgently needed.

One attractive possibility to achieve enhanced transfection and protection of DNA nanostructures is to take advantage of virus particles $(22,23)$. Viruses are natural transfection vectors and previous studies have already shown the possibility of using long double-stranded DNA or drug-loaded DNA micelles as templates to gain virus capsid protein -coated structures (24-26). Here, we show in detail how DNA origami nanostructures can be coated and encapsulated using virus capsid proteins. For this, we utilize cowpea chlorotic mottle virus (CCMV), which has been successfully used in encapsulation of various macromolecules $(27,28)$ and as a component in proteinbased crystals and superlattices (29-31). In brief, we combine ligated rectangular DNA origami templates $(92 \mathrm{~nm} \times 72 \mathrm{~nm} \times 2 \mathrm{~nm})$ with purified CCMV capsid protein (CP) dimers (32) in conditions where the self-assembly of proteins alone into higherorder structures is prevented.(33). We show that CPs bind effectively to the surface of negatively charged DNA origami due to their positively charged N-terminus, and adapt configurations remarkably different from the naturally occurring icosahedral capsid structure. 


\section{Materials}

\subsection{DNA origami preparation}

\subsubsection{DNA origami materials}

1. 7249 nucleotides long viral single-stranded DNA (ssDNA), M13mp18 (New England Biolabs or Tilibet Nanosystems), at $100 \mathrm{nM}$ concentration.

2. Set of short staple strands (Integrated DNA Technologies), at $100 \mu \mathrm{M}$. concentration. In rectangular DNA origami, sequences of the 128 core staple strands of the rectangular shape can be found from Ref. (4).

3. 10× TAE buffer with magnesium: $400 \mathrm{mM}$ tris(hydroxymethyl)aminomethane (Tris), $190 \mathrm{mM}$ acetic acid, $10 \mathrm{mM}$ ethylenediaminetetraacetic acid (EDTA), $125 \mathrm{mM}$ magnesium acetate $(\mathrm{MgAc})$ or magnesium chloride $\left(\mathrm{MgCl}_{2}\right), \mathrm{pH}$ $\sim 8.3$.

4. (Optional ligation): 10× Kinase reaction buffer (New England Biolabs), T4 Polynucleotide Kinase (New England Biolabs), 10× Ligase reaction buffer (New England Biolabs) and T4 DNA Ligase (New England Biolabs).

\subsubsection{Purification of DNA origami}

1. Millipore Amicon Ultra Centrifugal Filters, $0.5 \mathrm{~mL}$ with $100 \mathrm{kDa}$ molecular weight cut-off (MWCO).

2. Origami buffer: Hepes/ $\mathrm{NaOH}$ buffer (6.5 mM Hepes, $2.0 \mathrm{mM} \mathrm{NaOH}, \mathrm{pH}$ 6.8).

\subsection{CCMV CP isolation.}

1. Slide-A-Lyzer® Mini or similar dialysis units (3.5 kDa MWCO). 
2. Solution of native CCMV: CCMV $\left(10 \mathrm{mg} \mathrm{L}^{-1}\right)$ in acetate buffer $(100 \mathrm{mM}$ NaAc, 1 mM EDTA, $1 \mathrm{mM} \mathrm{NaN}_{3}$, pH 5).

3. CCMV capsid disassembly buffer: (50 mM Tris $+\mathrm{HCl}$ (Tris-HCl), $500 \mathrm{mM}$ $\mathrm{CaCl}_{2}, 1 \mathrm{mM}$ dithiothreitol (DTT), $\left.\mathrm{pH} 7.5\right)$.

4. CPs clean buffer: (50 mM Tris-HCl, $150 \mathrm{mM} \mathrm{NaCl,} 1 \mathrm{mM}$ DTT, $\mathrm{pH}$ 7.5) Note that the ready CP solution should be used within one week (in order to avoid degradation).

\subsection{Concentration and purity}

Cuvette: Quartz cuvette with $0.3 \mathrm{~cm}$ light path.

\subsection{Encapsulation procedure}

1. DNA origami solution $\sim 8 \mathrm{nM}$.

2. CP solution $\sim 50 \mu \mathrm{M}$.

3. $\quad 1.5 \mathrm{M} \mathrm{NaCl}$ solution.

\subsection{Characterization}

2.5.1. Transmission Electron Microscopy (TEM)

1. TEM grids: Carbon film grids on 300 hex mesh copper $(\mathrm{CF} 300 \mathrm{H}-\mathrm{Cu}$, Electron Microscopy Sciences)

2. Negative stain: (0.5 wt. \% uranyl acetate in Milli-Q water).

3. Filter paper.

4. Milli-Q water. 
1. Agarose gel: prepare $1 \%$ agarose gels by dissolving $1 \mathrm{~g}$ of agarose into 100 $\mathrm{mL}$ of $1 \times$ TAE buffer (40 mM Tris, $19 \mathrm{mM}$ acetic acid, $1 \mathrm{mM}$ EDTA, $11 \mathrm{mM} \mathrm{MgAc}$ or $\mathrm{MgCl}_{2}$ ). Mix and boil the solution for $30 \mathrm{~s}$, allow to cool and stain with $30 \mu \mathrm{L}$ of ethidium bromide (EthBr) solution $\left(0.625 \mathrm{mg} \mathrm{L}^{-1}\right)$.

2. Running buffer: $1 \times \mathrm{TAE}$ (see above) with $11 \mathrm{mM} \mathrm{MgAc}$ or $\mathrm{MgCl}_{2}$.

3. The DNA origami-CP samples: Prepare the samples $1 \mathrm{~h}$ before running the agarose gel.

4. $6 \times$ loading dye (New England Biolabs).

5. M13mp18 ssDNA (New England Biolabs).

\section{Methods}

\subsection{DNA origami preparation}

The fabricated shape is a $72 \mathrm{~nm}$ x $92 \mathrm{~nm}$ x $2 \mathrm{~nm}$ rectangular origami (see Note 1). The structure comprises of a 7249 bases long M13mp18 plasmid scaffold and 128 short oligonucleotides that fold the scaffold into a desired shape in a thermal annealing process. The staple design, core staple sequences and thermal ramp for folding have been adapted from Ref. (4) (see Note 2). After DNA origami formation by thermal annealing, the origami structures can be optionally ligated using T4 DNA ligase (see Note 3). The excess staple strands are removed after structure formation by a non-destructive spin-filtering procedure.

\subsubsection{DNA origami annealing}

This is a recipe for a ligated version of origami (if ligation is omitted, kinase reaction buffer (step number 3) and kinase (step number 5) can be replaced by in total $8 \mu \mathrm{L}$ of 
distilled water). The structures are prepared as $50 \mu \mathrm{L}$ quantities by mixing the following components:

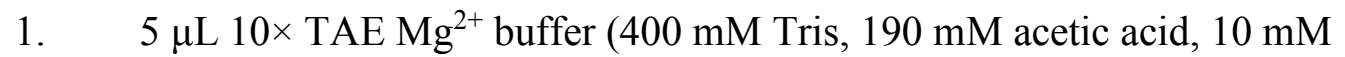
EDTA, $125 \mathrm{mM} \mathrm{MgAc}$ or $\mathrm{MgCl}_{2}$ ).

2. $\quad 25.5 \mu \mathrm{L}$ distilled water.

3. $5 \mu \mathrm{L} 10 \times$ kinase reaction buffer.

4. $\quad 6.1 \mu \mathrm{L}$ staple strand mix (each staple at $0.781 \mu \mathrm{M}$ concentration)

The staple strand mix is prepared by pipetting equal amounts of each 128 staple strands $(10 \mu \mathrm{M})$ and mixing them together. This results in $0.781 \mu \mathrm{M}$ concentration for each staple strand in the staple strand mix.

5. $\quad 3 \mu \mathrm{L} \mathrm{T} 4$ polynucleotide kinase (see Note 3 ).

6. $\quad 5.4 \mu \mathrm{L}$ of $93 \mathrm{nM}$ M13mp18 ssDNA.

The concentration of the scaffold strand in the total reaction volume of $50 \mu \mathrm{L}$ is 10 $\mathrm{nM}$. The staple strands are used in 10 times excess compared to the scaffold strand.

Thermal annealing ramp: The solution is kept 1 hour at $37^{\circ} \mathrm{C}$, which is the optimum operational temperature for kinase, and immediately after that the origamis can be folded in an annealing process using a thermal cycler: The solution is annealed from $90{ }^{\circ} \mathrm{C}$ to $20^{\circ} \mathrm{C}$ at a rate of $1{ }^{\circ} \mathrm{C} \min ^{-1}$ using $0.1^{\circ} \mathrm{C}$ steps (i.e. $0.1^{\circ} \mathrm{C}$ decrease every 6 seconds). After folding, the final concentration of DNA origami is $10 \mathrm{nM}$ (assuming $100 \%$ yield in folding).

\subsubsection{Optional DNA origami ligation procedure}


Ligation is carried out using T4 DNA ligase. The substances should be mixed in the order as listed below. The ligation procedure is prepared using $100 \mu \mathrm{L}$ quantities. After mixing, the solution is protected from light and let to incubate overnight at room temperature. The concentration of the DNA origami is diluted to $1 \mathrm{nM}$.

1. $9 \mu \mathrm{L} 10 \times \mathrm{TAE}_{\mathrm{Mg}^{2+}}$ buffer $(400 \mathrm{mM}$ Tris, $190 \mathrm{mM}$ acetic acid, $10 \mathrm{mM}$ EDTA, $125 \mathrm{mM} \mathrm{MgAc}$ or $\mathrm{MgCl}_{2}$ ).

2. $67 \mu \mathrm{L}$ distilled water.

3. $9 \mu \mathrm{L} 10 \times$ ligase reaction buffer.

4. $\quad 10 \mu \mathrm{L}$ annealed origami solution.

5. $5 \mu \mathrm{L}$ T4 DNA ligase

\subsubsection{Purification of DNA origami}

Most of the excess staples can be removed in a non-destructive spin-filtering process. Simultaneously, the buffer is exchanged (from TAE-based buffer to Hepes/ $\mathrm{NaOH}$ buffer). For filtering, $0.5 \mathrm{~mL}$ Millipore Amicon Ultra Centrifugal Filters with 100 kDa MWCO are used. Filtration steps are described in detail below.

1. $500 \mu \mathrm{L}$ of ligated DNA origami solution is injected into the filter. If ligation is not used, dilute $50 \mu \mathrm{L}$ of DNA origami solution to $500 \mu \mathrm{L}$ using Hepes/ $\mathrm{NaOH}$ buffer. 2. Solution is spun for $3 \mathrm{~min}$ using $14,000 \mathrm{rcf}$ and the flowthrough is discarded. 3. $450 \mu \mathrm{L}$ of Hepes/ $\mathrm{NaOH}$ buffer is added to the filter and centrifuged again for 3 min using 14,000 rcf.

4. The sample is spun in total 4 times repeating the procedure described above. 5. After the last spinning the remaining solution can be gently pipetted out from the filter unit. After that the filter is turned upside down in a fresh container and spun 2 min using 1,000 rcf in order to collect the rest of the solution. 
Typically, after filtration the volume of the solution is brought from $500 \mu \mathrm{L}$ down to 17-20 $\mu \mathrm{L}$. Dilute the solution back to $50 \mu \mathrm{L}$ by adding Hepes/ $\mathrm{NaOH}$ origami buffer. This results in pure DNA origami at approximately $10 \mathrm{nM}$ concentration (assuming $100 \%$ yield in spin-filtering) (see Note 4).

\subsection{CCMV CP isolation.}

1. Disassembly of CCMV: Dialyze $20-40 \mu \mathrm{L}$ of the CCMV stock solution (10 $\mathrm{mg} \mathrm{L}^{-1}$ ) against disassembly buffer for at least 8 hours using Slide-A-Lyzer ${ }^{\circledR}$ Mini or similar dialysis units (3.5 kDa MWCO).

2. CP isolation: Collect the solution inside the dialysis unit and centrifuge it overnight $\left(17,000 \mathrm{rcf}, 4^{\circ} \mathrm{C}\right)$. Collect the resulting supernatant carefully without touching the RNA pellet (note that sometimes the RNA pellet can be relatively faint). Dialyze the supernatant against clean buffer using dialysis units (3.5 kDa MWCO). Storing CP solution: Collect the solution inside the dialysis unit and dilute it with clean buffer if needed (see Note 5).

\subsection{Concentration and purity}

Carry out measurements at room temperature with a UV/Vis spectrometer (e.g. PerkinElmer LAMBDA 950). Use a quartz cuvette with a $0.3 \mathrm{~cm}$ light path. Subtract a reference spectra (blank buffer) from the spectra of actual samples.

\subsection{1. $C P s$}

Determine the $\mathrm{CP}$ concentration and purity by using the Beer-Lambert relationship, $A_{280}=\varepsilon_{280} \mathrm{CPP} l$, where $A_{280}$ is absorbance at $280 \mathrm{~nm}$ wavelength, $\varepsilon_{280}$ is the calculated 
extinction coefficient for CCMV protein monomer $\left(23,590 \mathrm{M}^{-1} \mathrm{~cm}^{-1}\right)$ and $l$ is the length of the light path in centimeters $(0.3 \mathrm{~cm})$.

$\mathrm{CP}$ concentration in different batches typically varies between 70 and $160 \mu \mathrm{M}$. Purity can be determined from $A_{280} / A_{260}$ ratio, which can vary between 1.3 and 1.5 . The higher the ratio, the cleaner the $\mathrm{CP}$ solution.

\subsubsection{DNA origami}

DNA origami concentration ( $\left.c_{\mathrm{DNA}}\right)$ was estimated using Beer-Lambert relationship, $A_{260}=\varepsilon_{260} C_{\mathrm{DNA}}$, where $A_{260}$ is absorbance at $260 \mathrm{~nm}$ wavelength, $\varepsilon_{260}$ is the calculated extinction coefficient $\left(0.93 * 10^{8} \mathrm{M}^{-1} \mathrm{~cm}^{-1}\right)(34)$ and $l$ is the length of the light path in centimeters $(0.3 \mathrm{~cm})$.

\subsection{Encapsulation procedure}

1. Mix $10 \mu \mathrm{L}$ DNA origami solution $(\sim 8 \mathrm{nM})$ and $0-10 \mu \mathrm{L}$ of CP solution $(\sim 50$ $\mu \mathrm{M}$ or diluted to $5 \mu \mathrm{M}$ ). Prepare several samples with different CP/DNA base pair ratios (marked as $x$ ) (see Note 6). Adjust the final $\mathrm{NaCl}$ concentration for all samples to $150 \mathrm{mM}$ by adding appropriate amount of $1.5 \mathrm{M} \mathrm{NaCl}$.

\section{(Insert table 1)}

2. Incubate at $4{ }^{\circ} \mathrm{C}$ for $1 \mathrm{~h}$.

3. Analyze the samples as described below.

\subsection{Characterization}




\subsubsection{Transmission Electron Microscopy (TEM)}

1. Prepare samples on carbon-coated grids by placing a $3 \mu \mathrm{L}$ drop of the sample solution on the grid. Leave the sample drop on the grid for 1 min after which the excess solution can be blotted away with a piece of filter paper. Allow the samples to dry.

2. Wash the sample with $3 \mu \mathrm{L}$ drop of Milli-Q water.

3. Stain the samples negatively by applying $3 \mu \mathrm{L}$ of stain $(0.5 \mathrm{wt}$. $\%$ uranyl acetate in Milli-Q water) onto the grid and remove immediately the excess stain with a piece of filter paper. Repeat the stain procedure once and dry the sample for at least 5 min before imaging.

\section{(Insert Figure 1)}

\subsubsection{Gel electrophoretic mobility shift assay (EMSA)}

1. Sample preparation: Mix $14 \mu \mathrm{L}$ of the DNA origami-CP complex solution and add $1 \mu \mathrm{L}$ of $6 \times$ loading dye.

2. Load the wells with $15 \mu \mathrm{L}$ of sample solution.

3. Run the gels with a constant voltage of $90 \mathrm{~V}$ for $45 \mathrm{~min}$ and image under UV light.

(Insert Figure 2.)

\section{Notes}


1. In this protocol, the formation of the DNA origami-CP complexes is demonstrated using a 2D rectangular DNA origami. However, the coating method can be generalized and equally used for 3D origami shapes. 3D structures should be folded using a longer thermal ramp (e.g. lowering the temperature from $65{ }^{\circ} \mathrm{C}$ to 40 ${ }^{\circ} \mathrm{C}$ at a rate of $1{ }^{\circ} \mathrm{C}$ per 3 hours). In addition, 3D structures usually need more magnesium $(20 \mathrm{mM})$ than $2 \mathrm{D}$ structures $(12.5 \mathrm{mM})$ for the successful folding.

2. The side-strands of the original DNA origami design (4) (strands at the edges of the design) are omitted in order to avoid undesired aggregation of DNA origamis, i.e. to prevent their stacking to each other via blunt ends. It is highly recommended to take this stacking interaction into account if different DNA origami designs are used.

3. T4 polynucleotide kinase is applied for adding phosphate at the 5' end of staple strands for the following optional ligation procedure. Ligation might improve the thermal stability of DNA structures (35).

4. To ensure the quality of the DNA origami folding and purification, the gel electrophoresis can be run (similarly as described in 2.5.1 and 3.5.1). M13mp18 scaffold strand can be used as a reference for the running speed of the DNA origami sample.

5. It is useful to start the procedure by fabricating the DNA origamis first (decent long-term storing properties) and prepare CP solution only after that. This is fairly important, since the CPs start to degrade within one week after the preparation (the N- 
terminus (first $\sim 30$ amino acids) of $\mathrm{CP}$ is known to degrade within weeks, even if the solution is stored at $\left.4{ }^{\circ} \mathrm{C}\right)(36)$.

6. At a ratio of $x=0.08$, the CPs start to bend the 2D DNA origami into tube-like conformations. When the ratio is increased to $x=0.64$, round complexes are observed instead of tube-shaped structures. The tube-formation and folding of the rectangles could be attributed to a high flexibility and significantly twisted natural shape of a used DNA origami (twisting occurs when the origami is designed using a square lattice packing $(37,38))$. Therefore, if more rigid 3D origamis are used in the complex-formation, twisting and bending might not appear as prominent. The observed phenomena are likely caused by an electrostatic effect: the (positive) charge residues of CPs could effectively reduce repulsion between the DNA helices and further facilitate the complete folding of rectangles (similar folding can be observed when rectangular origamis are anchored onto substrates under localized electric fields $(11,39,40))$.

\section{Acknowledgement}

Financial support from the Academy of Finland (grants 263504, 267497, 273645, 286845), Emil Aaltonen Foundation and Biocentrum Helsinki is gratefully acknowledged. This work was carried out under the Academy of Finland Centers of Excellence Programme (2014-2019) and made use of the Aalto Nanomicroscopy Centre (Aalto NMC) premises. 


\section{References}

1. Seeman, N.C. (1982) Nucleic acid junctions and lattices. J Theor Biol 99, 237-247.

2. Seeman, N.C. (2010) Nanomaterials based on DNA. Annu Rev Biochem 79, 65-87.

3. Linko, V. and Dietz, H. (2013) The enabled state of DNA nanotechology. Curr Opin Biotechnol 24, 555-561.

4. Rothemund, P.W.K. (2006) Folding DNA to create nanoscale shapes and patterns. Nature 440, 297-302.

5. Douglas, S.M., Dietz, H., Liedl, T., Högberg, B., Graf, F., and Shih, W.M. (2009) Self-assembly of DNA into nanoscale three-dimensional shapes. Nature 459, 414418.

6. Fu, J., Liu, M., Liu, Y., Woodbury, N.W, and Yan, H. (2012) Interenzyme substrate diffusion for an enzyme cascade organized on spatially addressable DNA nanostructures. J Am Chem Soc 134, 5516-5519.

7. Kuzyk, A., Schreiber, R., Fan, Z., Pardatscher, G., Roller, E.-M., Högele, A., Simmel, F.C., Govorov, A.O., and Liedl, T. (2012) DNA-based self-assembly of chiral plasmonic nanostructures with tailored optical response. Nature 483, 311-314. 
8. Maune, H.T., Han, S., Barish, R.D., Bockrath, M., Goddard III, W.A., Rothemund, P.W.K., and Winfree, E. (2010) Self-assembly of carbon nanotubes into twodimensional geometries using DNA origami templates. Nature Nanotech 5, 61-66.

9. Linko, V., Eerikäinen, M., and Kostiainen, M.A. (2015) A modular DNA origamibased enzyme cascade nanoreactor. Chem Commun 51, 5351-5354.

10. Shen, B., Linko, V., Tapio, K., Kostiainen, M.A., and Toppari, J.J. (2015)

Custom-shaped metal nanostructures based on DNA origami silhouettes. Nanoscale 7, 11267-11272.

11. Shen, B., Linko, V., Dietz, H., and Toppari, J.J. (2015) Dielectrophoretic trapping of multilayer DNA origami nanostructures and DNA origami-induced local destruction of silicon dioxide. Electrophoresis 36, 255-262.

12. Linko, V., Shen, B., Tapio, K., Toppari, J.J., Kostiainen, M.A., and Tuukkanen, S. (2015) One-step large-scale deposition of salt-free DNA origami nanostructures. Sci Rep 5, 15634.

13. Chen, Y.-J., Groves, B., Muscat, R.A., and Seelig, G. (2015) DNA nanotechnology from the test tube to the cell. Nature Nanotech 10, 748-760.

14. Linko, V., Ora, A., and Kostiainen, M.A. (2015) DNA nanostructures as smart drug-delivery vehicles and molecular devices. Trends Biotechnol 33, 586-594. 
15. Ko, S.-H., Liu, H., Chen, Y., and Mao, C. (2008) DNA nanotubes as combinatorial vehicles for cellular delivery. Biomacromolecules 9, 3039-3043.

16. Schüller, V.J., Heidegger, S., Sandholzer, N., Nickels, P.C., Suhartha, N.A., Endres, S., Bourquin, C., and Liedl, T. (2011) Cellular immunostimulation by CpGsequence-coated DNA origami structures. ACS Nano 5, 9696-9702.

17. Zhao, Y.-X., Shaw, A., Zeng, X., Benson, E., Nyström, A.M., and Högberg, B. (2012) DNA origami delivery system for cancer therapy with tunable release properties. ACS Nano 6, 8684-8691.

18. Zhang, Q., Jiang, Q., Li, N., Dai, L., Liu, Q., Song, L., Wang, J., Li, Y., Tian, J., Ding, B., and Du, Y. (2014) DNA origami as an in vivo drug delivery vehicle for cancer therapy. ACS Nano 8, 6633-6643.

19. Okholm, A.H., Nielsen, J.S., Vinther, M., Sørensen, R.S., Schaffert, D., and Kjems, J. (2014) Quantification of cellular uptake of DNA nanostructures by qPCR. Methods 67, 193-197.

20. Brglez, J., Nikolov, P., Angelin, A., and Niemeyer, C.M. (2015) Designed intercalators for modification of DNA origami surface properties. Chem Eur J 21, 9440-9446.

21. Perrault, S.D. and Shih, W.M. (2014) Virus-inspired membrane encapsulation of DNA nanostructures to achieve in vivo stability. ACS Nano 8, 5132-5140. 
22. Ma, Y., Nolte. R.J.M., and Cornelissen, J.J.L.M. (2012) Virus-based nanocarriers for drug delivery. Adv Drug Delivery Rev 64, 811-825.

23. Yildiz, I., Shukla, S., and Steinmetz, N.F. (2011) Applications of viral nanoparticles in medicine. Curr Opin Biotechnol 22, 901-908.

24. Mukherjee, S., Pfeifer, C.M., Johnson, J.M., Liu, J., and Zlotnick, A. (2006) Redirecting the coat protein of a spherical virus to assemble into tubular nanostructures. J Am Chem Soc 128, 2538-2539.

25. Kwak, M., Minten, I.J., Anaya, D.-M., Musser, A.J., Brasch, M., Nolte, R.J.M., Müllen, K., Cornelissen, J.J.L.M., and Herrmann, A. (2010) Virus-like particles templated by DNA micelles: A general method for loading virus nanocarriers. $J \mathrm{Am}$ Chem Soc 132, 7834-7835.

26. Geiger, F.C., Eber, F.J., Eiben, S., Mueller, A., Jeske, H., Spatz, J.P., and Wege, C. (2013) TMV nanorods with programmed longitudinal domains of differently addressable coat proteins. Nanoscale 5, 3808-3816.

27. Douglas, T. and Young, M. (1998) Host-guest encapsulation of materials by assembled virus protein cages. Nature 393, 152-155. 
28. Young, M., Willits, D., Uchida, M., and Douglas, T. (2008) Plant viruses as biotemplates for materials and their use in nanotechnology. Annu Rev Phytopathol 46, 361-384.

29. Kostiainen, M.A., Hiekkataipale P., Laiho, A., Lemieux, V., Seitsonen, J., Ruokolainen, J., and Ceci, P. (2013) Electrostatic assembly of binary nanoparticle superlattices using protein cages. Nature Nanotech 8, 52-56.

30. Mikkilä, J., Rosilo, H., Nummelin, S., Seitsonen, J., Ruokolainen J., and Kostiainen, M.A. (2013) Janus-dendrimer-mediated formation of crystalline virus assemblies. ACS Macro Lett 2, 720-724.

31. Liljeström, V., Mikkilä, J., and Kostiainen, M.A. (2014) Self-assembly and modular functionalization of three-dimensional crystals from oppositely charged proteins. Nat Commun 5, 4445.

32. Mikkilä, J., Eskelinen, A.-P., Niemelä, E.H., Linko, V., Frilander, M.J., Törmä, P., and Kostiainen, M.A. (2014) Virus-encapsulated DNA origami nanostructures for cellular delivery. Nano Lett 14, 2196-2200.

33. Bruinsma, R.F., Gelbart, W.M., Reguera, D., Rudnick, J., and Zandi, R. (2003) Viral self-assembly as a thermodynamic process. Phys Rev Lett 90, 248101. 
34. Hung, A.M., Micheel, C.M., Bozano, L.D., Osterbur, L.W., Wallraff, G.M., and Cha, J.N. (2010) Large-area spatially ordered arrays of gold nanoparticles directed by lithographically confined DNA origami. Nature Nanotech 5, 121-126.

35. O’Neill, P., Rothemund, P.W.K., Kumar, A., and Fygenson, D.K. (2006) Sturdier nanotubes via ligation. Nano Lett 6, 1379-1383.

36. Tang, J., Johnson, J.M., Dryden, K.A., Young, M.J., Zlotnick, A., and Johnson, J.E. (2006) The role of subunit hinges and molecular "switches" in the control of viral capsid polymorphism. $J$ Struct Biol 154, 59-67.

37. Ke, Y., Douglas, S.M., Liu, M., Sharma, J., Cheng, A., Leung, A., Liu, Y., Shih, W.M., and Yan, H. (2009) Multilayer DNA origami packed on a square lattice. J Am Chem Soc 131, 15903-15908.

38. Castro, C.E., Kilchherr, F., Kim, D.-N., Shiao, E.L., Wauer, T., Wortmann, P., Bathe, M., and Dietz, H. (2011) A primer to scaffolded DNA origami. Nat Methods 8, 221-229.

39. Kuzyk, A., Yurke, B., Toppari, J.J., Linko, V., and Törmä, P. (2008)

Dielectrophoretic trapping of DNA origami. Small 4, 447-450.

40. Linko, V., Paasonen, S.-T., Kuzyk, A., Törmä, P., and Toppari, J.J. (2009) Characterization of the conductance mechanisms of DNA origami by AC impedance spectroscopy. Small 5, 2382-2386. 


\section{Sample details}

\begin{tabular}{|l|l|l|l|l|l|}
\hline Sample number & Ref. & 1 & 2 & 3 & 4 \\
\hline$x=\mathrm{n}(\mathrm{CP}) / \mathrm{n}(\mathrm{DNA} b \mathrm{~b})$ & & 0.05 & 0.1 & 0.5 & 1 \\
\hline & & & & & \\
\hline $\mathrm{V}(\mathrm{HEPES} / \mathrm{NaOH}, \mu \mathrm{L})$ & 53 & 53 & 53 & 53 & 53 \\
\hline $\mathrm{V}(\mathrm{NaCl} 1.5 \mathrm{M}, \mu \mathrm{L})$ & 7 & 7 & 7 & 7 & 7 \\
\hline $\mathrm{V}(\mathrm{DNA}$ origami, $\mu \mathrm{L})$ & 10 & 10 & 10 & 10 & 10 \\
\hline $\mathrm{V}(\mathrm{clean}$ buffer, $\mu \mathrm{L})$ & 10 & 5 & 0 & 5 & 0 \\
\hline V $(\mathrm{CP}$ diluted $10 \mathrm{x}, \mu \mathrm{L})$ & & 5 & 10 & & \\
\hline V $(\mathrm{CP}, \mu \mathrm{L})$ & & & & 5 & 10 \\
\hline V (total, $\mu \mathrm{L})$ & 80 & 80 & 80 & 80 & 80 \\
\hline
\end{tabular}

Table 1. Amounts of different materials required for the encapsulation. 


\section{TEM micrographs}
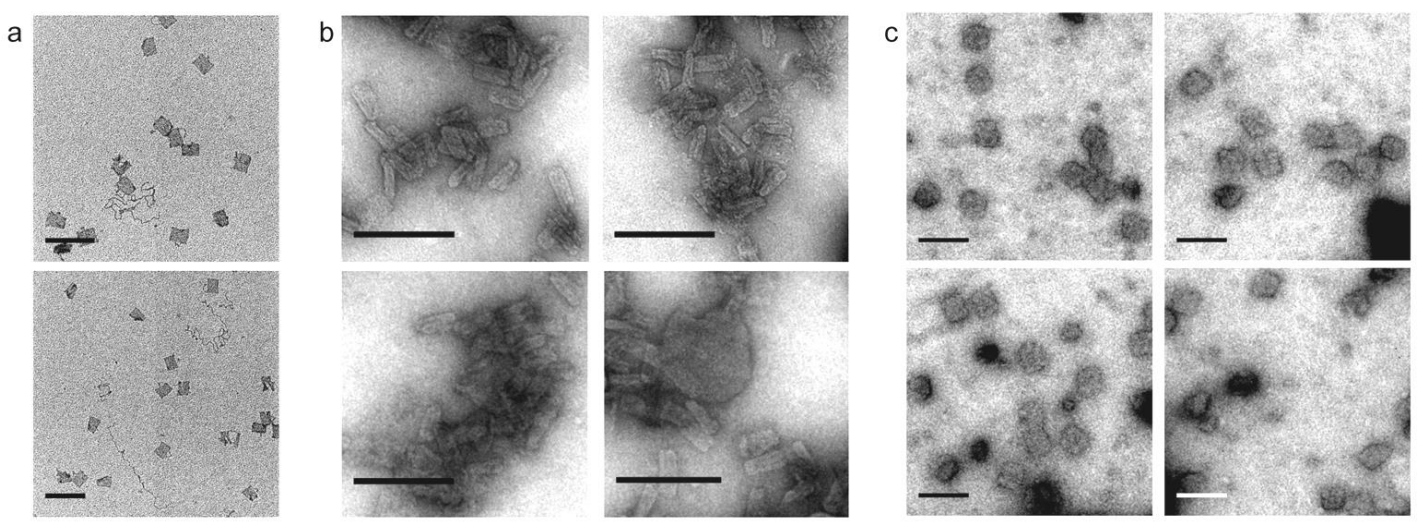

Figure 1. TEM micrographs from samples $x=0$ (a), $x=0.08$ (b) and $x=0.64$ (c) revealing the interaction between DNA origamis and CPs. The scale bar in each figure is $200 \mathrm{~nm}$. Reprinted with permission from Nano Letters 2014, 14, 2196-2200. Copyright 2014 American Chemical Society. 


\section{Gel images}

CP

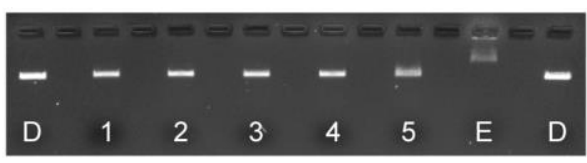

$\mathrm{CP} \Delta \mathrm{N}$

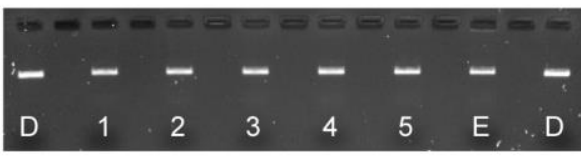

Avidin

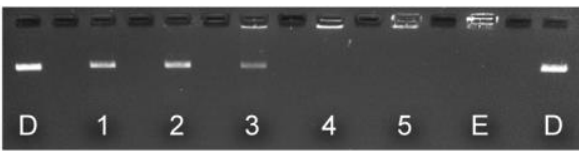

BSA

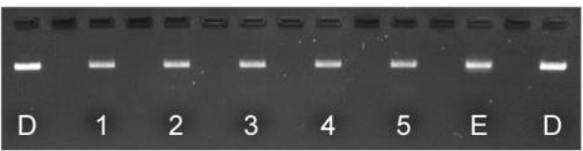

Figure 2. EMSA gels of four different protein samples mixed with constant amounts of spin-filtered

DNA origami structures in $150 \mathrm{mM} \mathrm{NaCl}$ solution. Protein concentration gradually increases from lane

1 to lane $\mathrm{E}(x=0, x=0.016, x=0.032, x=0.08, x=0.32, x=3.2)$. Figure shows that $\mathrm{CP}$ binds on

DNA origami and hinders the electrophoretic mobility of complexes when the ratio is high $(x=0.32-$

3.2) also in $150 \mathrm{mM} \mathrm{NaCl}$ solution unlike $\mathrm{CP}$ without $\mathrm{N}$-terminus $(\mathrm{CP} \Delta \mathrm{N})$. In the case of avidin, which has a high positive net surface charge, electrophoretic mobility of DNA origami is decreased already at low protein concentrations $(x=0.032-0.08)$. In contrast, similarly varied concentrations of bovine serum albumin (BSA) showed no effect on electrophoretic mobility of origamis. Reprinted with permission from Nano Letters 2014, 14, 2196-2200. Copyright 2014 American Chemical Society. 